\title{
Analisis Penyebaran Virus Covid-19 di Provinsi Sumatera Selatan Menggunakan Metode Interpolasi Lagrange
}

\author{
Widya Rahmadani ${ }^{1}$, Sagita Charolina Sihombing ${ }^{2 *}$ \\ ${ }^{1}$ Mahasiswa Program Studi Fisika Fisika, FMIPA Universitas PGRI Palembang, \\ Palembang 30251, Indonesia \\ ${ }^{2}$ Program Studi Fisika, FMIPA Universitas PGRI Palembang, \\ Palembang 30251, Indonesia. \\ *e-mail: sagita.charolina@yahoo.com
}

\begin{abstract}
Abstrak
Coronavirus Disease 2019 (COVID-19) terkonfirmasi masuk ke Indonesia pada bulan Maret 2020. Penyebaran virus ini terjadi dengan sangat cepat. Setiap hari jumlah pasien yang terdampak virus ini terus bertambah dan menyebar di seluruh Provinsi di Indonesia, salah satunya di Provinsi Sumatera Selatan. Pemerintah Sumatera Selatan dituntut untuk mengambil langkah cepat dalam menangani penyebaran virus ini. Oleh sebab itu, perlu adanya estimasi penyebaran virus corona di Sumatera Selatan, sehingga Pemerintah dapat segera melakukan persiapan baik dalam persiapan obat-obatan ataupun tempat isolasi bagi pasien. Dalam penelitian ini digunakan metode Lagrange untuk memprediksi penyebaran virus corona di Sumatera Selatan. Dari hasil penelitian diperoleh bahwa metode interpolasi Lagrange dapat digunakan untuk meramalkan data kasus virus corona baik untuk kasus pasien positif, pasien sembuh maupun pasien meninggal dari awal masuknya kasus pertama di Provinsi Sumatera Selatan yaitu bulan Maret sampai Mei 2020.
\end{abstract}

Kata Kunci: Coronavirus Disease, Provinsi Sumatera Selatan, Metode Lagrange, Estimasi

\section{Analysis of the Spread of the Covid-19 Virus in the Provinces South Sumatra Using the Lagrange Interpolation Method}

\author{
Abstract \\ Coronavirus Disease 2019 (COVID-19) was confirmed to enter Indonesia in March
} 2020. The spread of this virus has occurred very quickly. Every day the number of patients affected by this virus continues to increase and spread throughout the provinces in Indonesia, one of which is in the Province of South Sumatra. The South Sumatra government is required to take quick steps in dealing with the spread of this virus. Therefore, it is necessary to estimate the spread of the corona virus in South Sumatra, so that the Government can immediately make preparations both in preparation of medicines or in isolation places for patients. In this study, the Lagrange method was used to predict the spread of the corona virus in South Sumatra. From the results of the study, it was found that the Lagrange interpolation method can be used to predict data on cases of the corona virus for positive cases, recovered patients and patients who died from the initial entry of the first case in South Sumatra Province, namely March to May 2020.

Keywords: Coronavirus Disease, South Sumatra Province, Lagrange Method, Estimation.

\section{PENDAHULUAN}

Pada awal tahun 2020, dunia digemparkan dengan menyebarnya virus baru yaitu coronavirus jenis baru, yang merupakan salah satu jenis virus yang masih berkerabat dengan virus penyebab
SARS. Virus ini ditemukan pertama kali di Kota Wuhan China, tepatnya di ibukota Hubei, China Tengah. Pada awal Desember 2019 seorang pasien didiagnosa menderita pneumonia yang 
tidak biasa, dan pada tanggal 31 Desember kantor Regional Organisasi Kesehatan Dunia (WHO) di Beijing telah menerima pemberitahuan tentang sekelompok pasien dengan pneumonia yang tidak diketahui penyebabnya dari kota yang sama. World Health Organization memberi nama virus tersebut sebagai Severe Acute Respiratory Syndrome Coronavirus-2 (SARS-CoV-2) dan nama penyakitnya disebut Coronavirus Disease 2019 (COVID-19) (WHO, 2020)

Menyebarnya virus corona yang sangat cepat bahkan mencapai skala Internasional sehingga disebut sebagai pandemik Covid-19, membuat dunia resah termasuk di Indonesia. Coronavirus ini merupakan jenis virus baru, sehingga banyak pihak yang tidak tahu bahkan tidak mengerti cara menanggulangi virus tersebut (Telaumbanua, 2020). Di Indonesia sendiri dalam pencegahan penularan Covid-19 diambil kebijakan social distancing atau Pembatasan Sosial Berskala Besar (PSBB) di tiap-tiap daerah sebagai langkah awal untuk menanggulangi pandemic ini.

Penyebaran virus corona di Indonesia terbilang cukup cepat, data terakhir yang didapat dari situs https://covid19.go.id untuk periode 10 Juni 2020, sebanyak 34.316 kasus pasien positif, 12.129 kasus pasien sembuh dan 1.959 kasus pasien meninggal. Diketahui bahwasanya virus corona terdeteksi di Indonesia sebagai kasus pertama pada tanggal 2 Maret 2020, berita ini diumumkan secara resmi oleh Presiden Joko Widodo di Istana Negara. Dua warga Negara Indonesia yang berstatus positif tersebut ternyata sempat melakukan kontak dengan warga Jepang yang datang ke-Indonesia. (Litbang KOMPAS, 2020)

Dalam kondisi saat ini, virus corona bukanlah suatu wabah yang bisa diabaikan atau bahkan diremehkan begitu saja. Jika dilihat dari gejalanya, orang awam akan mengira hanya sebatas influenza biasa, tetapi menurut analisis kedokteran virus ini cukup berbahaya dan mematikan. (Yunus dan Rezki, 2020) Terbukti dari data-data yang bisa didapatkan dari situs resmi covid-19 bahwasanya perkembangan penularan virus ini cukup signifikan dan sudah menyebar hampir di seluruh daerah di Indonesia, khusunya di Provinsi Sumatera Selatan. Di Sumatera Selatan ada beberapa wilayah yang termasuk ke dalam Zona Merah, disebabkan cepatnya penularan virus corona ini seperti Kota Palembang, Kota Prabumulih, Kota Lubuk Linggau, Kabupaten Ogan Komering Ulu (OKU) dan Kota Banyuasin. Bahkan Provinsi Sumatera Selatan berada pada urutan ke-7 untuk kasus konfirmasi tertinggi di Indonesia (Dinas Kesehatan Provinsi Sumatera Selatan, 2020)

Untuk

memprediksi

perkembangan dari penularan virus Covid-19 ini dapat dilakukan kegiatan peramalan, dimana peramalan (forecasting) adalah kegiatan mengestimasi apa yang akan terjadi pada masa yang akan datang (Sucipto dan Syaharuddin, 2018). Dalam penelitian ini akan dicari perkembangan dari penularan virus corona di Sumatera Selatan menggunakan data dimulai dari tanggal 24 Maret 2020 sampai 31 Mei 2020 untuk seluruh kasus yang terjadi di wilayah Sumatera Selatan dengan melakukan simulasi menggunakan metode interpolasi polinomial. Interpolasi adalah proses pencarian dan perhitungan nilai suatu fungsi yang grafiknya melewati sekumpulan titik yang diberikan. Interpolasi polinomial yang digunakan adalah interpolasi Lagrange dimana interpolasi ini sangat dikenal dalam metode numerik, karena menggunakan fungsi dalam bentuk polinomial. Hal penting yang perlu diperhatikan dalam mencari solusi interpolasi lagrange adalah perhitungan 
galat (error) dari perhitungan numerik terhadap hasil real-nya (solusi analitik) (Krisnawati, 2007).

Jenis penelitian ini adalah penelitian kualitatif. Data yang diperoleh kemudian dianalisis secara deskripsi untuk menemukan perkembangan virus corona di Sumatera Selatan melalui analisis data yang ada. Data utama yang digunakan pada penelitian ini adalah data time series Covid-19 di Sumatera Selatan dimulai dari kasus pertama pada tanggal 24 Maret 2020 sampai 31 Mei 2020. Analisis perkembangan virus covid-19 ini diambil dari data pasien yang positif, sembuh dan mengalami kematian yang diakumulasi perhari. Sehingga target dari penelitian ini adalah mengetahui prediksi perkembangan virus corona yang terjadi di Sumatera Selatan dengan mengumpulkan data penyebaran untuk pasien positif, sembuh dan meninggal dari setiap Kota atau Kabupaten dan mengambil jumlah akumulasi dari data tersebut dalam hitungan hari yang bersumber dari web resmi dinkes.sumselprov.go.id, untuk mengetahui perkembangan virus corona terupdate yang terjadi di Provinsi Sumatera Selatan.

\section{DASAR TEORI}

\section{Pengertian Virus Corona}

Coronavirus merupakan virus RNA strain tunggal positif, berkapsul dan tidak bersegmen. Coronavirus tergolong ordo Nidovirales, keluarga Coronaviridae. Struktur coronavirus membentuk struktur seperti kubus dengan protein $\mathrm{S}$ berlokasi di permukaan virus. Protein $\mathrm{S}$ atau spike protein merupakan salah satu protein antigen utama virus dan merupakan struktur utama untuk penulisan gen. Protein S ini berperan dalam penempelan dan masuknya virus ke dalam sel host (interaksi protein $\mathrm{S}$ dengan respektronya di sel inang) (Wang, 2020). Coronavirus bersifat sensitif terhadap panas dan secara efektif dapat dinonaktifkan oleh disenfektan mengandung klorin, pelarut lipid dengan suhu $56^{\circ} \mathrm{C}$ selama 30 menit, eter, alcohol, asam perioksiasetat, detergen non-ionik, formalin, oxidizing agent dan kloroform. Klorheksidin tidak efektif dalam menonaktifkan virus (Korsman, 2012).

Coronavirus disebut dengan virus zoonotic yaitu virus yang ditransmisikan dari hewan ke manusia. Banyak hewan liar yang dapat membawa pathogen dan bertindak sebagai vector untuk penyakit menular tertentu. Kelelawar, tikus bambu, unta dan musang merupakan host yang biasa ditemukan untuk Coronavirus. Coronavirus hanya bisa memperbanyak diri melalui sel host-nya. Virus tidak bisa hidup tanpa sel host. Setelah terjadi transmisi, virus masuk ke saluran napas atas kemudian bereplikasi di sel epitel saluran napas atas (melakukan siklus hidupnya). Setelah itu menyebar ke saluran napas bawah. Masa inkubasi virus sampai muncul penyakit sekitar 3-7 hari (PDPI, 2020).

Infeksi COVID-19 dapat menimbulkan gejala ringan, sedang atau berat. Gejala klinis utama yang muncul yaitu demam (suhu > $38{ }^{\circ} \mathrm{C}$ ), batuk, kesulitan bernapas. Selain itu dapat desertai dengan sesak memberat, fatigue, mialgia, gejala gastrointestinal seperti diare dan gejala saluran napas lain. Setengah dari pasien timbul sesak dalam satu minggu. Pada kasus berat perburukan secara cepat dan progresif. Pada beberapa pasien, gejala yang muncul ringan, bahkan tidak disertai dengan demam. Kebanyakan pasien memiliki prognosis baik, dengan sebagian kecil dalam kondisi kritis bahkan meninggal (PDPI, 2020).

\section{Interpolasi Lagrange}

Interpolasi Lagrange merupakan teknik yang popular, karena menggunakan fungsi dalam bentuk polinom. Interpolasi Lagrange tidak 
hanya berlaku untuk titik-titik yang berjarak sama dan membuat sebuah fungsi pendekatan tanpa harus menurunkan berkali-kali. Interpolasi Lagrange diterapkan untuk mendapatkan fungsi polynomial $f(\mathrm{x})$ berderajat tertentu yang melewati sejumlah titik data. Misalnya akan dicari fungsi polynomial berderajat satu (orde 1) yang melewati dua buah titik yaitu $\left(\mathrm{x}_{2}, \mathrm{y}_{2}\right)$ dan $\left(\mathrm{x}_{1}, \mathrm{y}_{1}\right)$, maka dapat ditulis persamaan linearnya sebagai berikut (Krisnawati, 2007) :

$y_{0}=a_{0}+a_{1} x_{0}$

$y_{1}=a_{0}+a_{1} x_{1}$

Dan grafik dari persamaan (1) dan (2) dapat digambarkan dalam Gambar 1. Sebagai berikut :

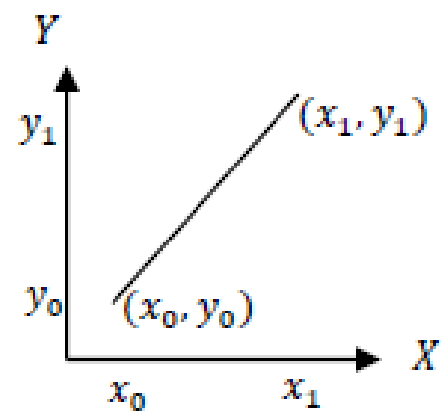

Gambar 1. Grafik Persamaan Garis Lurus dari 2 Titik

Persamaan (1) dan (2) dieliminasi diperoleh bentuk :

$a_{1}=\frac{y_{1}-y_{0}}{x_{1}-x_{0}}$

Dan subtitusi persamaan (3) ke persamaan (1) didapat :

$$
\begin{aligned}
& y_{0}=a_{0}+a_{1} x_{0} \\
& y_{0}-a_{1} x_{0}=a_{0} \\
& a_{0}=y_{0}-\left(\frac{y_{1}-y_{0}}{x_{1}-x_{0}}\right) \cdot x_{0}
\end{aligned}
$$

Kemudian subtitusikan persamaan (3) dan (4) ke fungsi linear diperoleh (Munir, 2003):

$$
\begin{aligned}
f(x) & =a_{0}+a_{1} x \\
& =\left(y_{0}-\left(\frac{y_{1}-y_{0}}{x_{1}-x_{0}}\right) \cdot x_{0}\right)+\left(\frac{y_{1}-y_{0}}{x_{1}-x_{0}}\right) \cdot x \\
& =y_{0}+\left(\frac{y_{1}-y_{0}}{x_{1}-x_{0}}\right) \cdot\left(x-x_{0}\right)
\end{aligned}
$$

$$
\begin{aligned}
& =\frac{y_{0}\left(x_{1}-x_{0}\right)+\left(y_{1}-y_{0}\right)\left(x-x_{0}\right)}{x_{1}-x_{0}} \\
& =\frac{y_{0} x_{1}-y_{0} x_{0}+y_{1} x-y_{1} x_{0}-y_{0} x+y_{0} x_{0}}{x_{1}-x_{0}} \\
& =\frac{\left(x_{1}-x\right) \cdot y_{0}+\left(x-x_{0}\right) \cdot y_{1}}{x_{1}-x_{0}} \\
& =\frac{\left(x_{1}-x\right)}{\left(x_{1}-x_{0}\right)} \cdot y_{0}+\frac{\left(x-x_{0}\right)}{\left(x_{1}-x_{0}\right)} \cdot y_{1} \\
& =\frac{\left(x-x_{1}\right)}{\left(x_{0}-x_{1}\right)} \cdot y_{0}+\frac{\left(x-x_{0}\right)}{\left(x_{1}-x_{0}\right)} \cdot y_{1} \\
& =L_{0}(x) y_{0}+L_{1}(x) y_{1}
\end{aligned}
$$

Maka persamaan polynomial Lagrange berderajat 1 adalah

$$
P_{1}(x)=\sum_{i=0}^{1} L_{1}(x) y_{1}
$$

Sedangkan bentuk umum polinom

Lagrange berderajat $\leq n$ untuk $(n+1)$

titik berbeda adalah

$P_{n}(x)=\sum_{i=1}^{n} L_{i}(x) y_{i}=L_{n}(x) y_{0}+L_{1}(x) y_{1}+\cdots+L_{n}(x) y_{0}$

yang dalam hal ini

$$
y_{i}, \quad \dot{i}=0,1,2, \ldots, n
$$

dan,

$L_{i}(x)=\prod_{\substack{j=0 \\ j \neq i}}^{n} \frac{\left(x-x_{j}\right)}{\left(x_{i}-x_{j}\right)}=\frac{\left(x-x_{j}\right)\left(x-x_{i}\right) \ldots\left(x-x_{i-1}\right)\left(x-x_{i+1}\right) \ldots\left(x-x_{n}\right)}{\left(x_{i}-x_{i}\right)\left(x_{i}-x_{1}\right) \ldots\left(x_{i}-x_{i-1}\right)\left(x_{i}-x_{i+1}\right) \ldots\left(x_{i}-x_{n}\right)}$

Adapun algoritma interpolasi Lagrange dapat dituliskan sebagai berikut (Krisnawati, 2007):

a. Tentukan jumlah titik yang diketahui. Untuk menginputkan titik yang diketahui dapat menggunakan dua array $\mathrm{X}$ dan $\mathrm{Y}$ dengan jumlah data $=$ dengan jumlah titiknya.

b. Mencari $\mathrm{L}_{\mathrm{i}}(\mathrm{x})$ dan $\mathrm{P}(\mathrm{x}) . \mathrm{L}_{\mathrm{i}}(\mathrm{x})$ didapat sejumlah titik yang diketahui, sehingga diperlukan perulangan sebanyak titik yang diketahui. Demikian pula $\mathrm{P}$ (x) merupakan jumlahan dari perkalian $\mathrm{y}_{\mathrm{i}}$ dan $\mathrm{L}_{\mathrm{i}}(\mathrm{x})$, sehingga memerlukan perulangan yang jumlahnya sama dengan proses pencarian $\mathrm{L}_{\mathrm{i}}(\mathrm{x})$. 
METODE PENELITIAN

Data Yang Digunakan

Data virus corona yang digunakan merupakan data pasien Covid-19 yang positif, sembuh dan meninggal dunia yang terjadi si Provinsi Sumatera Selatan. Data tersebut ditulis menggunakan Microsoft excel untuk melakukan prediksi yaitu data perhari yang terjadi di seluruh daerah di Provinsi Sumatera Selatan, mulai dari tanggal 24 Maret 2020 sampai dengan 31 Mei 2020 dengan masing-masing kasus positif, sembuh dan meninggal dunia. Adapun datanya bisa dilihat pada tabel 1 berikut:

Tabel 1. Data Kasus Virus Corona di Provinsi Sumatera Selatan

\begin{tabular}{|c|c|c|c|c|}
\hline Hari Ke- & Tanggal & Positif & Sembuh & Meninggal \\
\hline 1 & 24-Mar & 1 & 0 & 0 \\
\hline 2 & 25-Mar & 0 & 0 & 1 \\
\hline 3 & 26-Mar & 0 & 0 & 0 \\
\hline 4 & 27-Mar & 0 & 0 & 0 \\
\hline 5 & 28-Mar & 1 & 0 & 0 \\
\hline 6 & 29-Mar & 0 & 0 & 1 \\
\hline 7 & 30-Mar & 0 & 0 & 0 \\
\hline 8 & 31-Mar & 3 & 0 & 0 \\
\hline 9 & 1-Apr & 0 & 0 & 0 \\
\hline 10 & 2-Apr & 6 & 0 & 0 \\
\hline 11 & 3-Apr & 1 & 0 & 0 \\
\hline 12 & 4-Apr & 0 & 1 & 0 \\
\hline 13 & 5-Apr & 4 & 0 & 0 \\
\hline 14 & 6-Apr & 0 & 0 & 0 \\
\hline 15 & 7-Apr & 0 & 0 & 0 \\
\hline 16 & 8-Apr & 0 & 0 & 0 \\
\hline 17 & 9-Apr & 1 & 0 & 0 \\
\hline 18 & 10-Apr & 1 & 0 & 0 \\
\hline 19 & 11-Apr & 0 & 0 & 0 \\
\hline 20 & 12-Apr & 0 & 3 & 0 \\
\hline 21 & 13-Apr & 0 & 0 & 0 \\
\hline 22 & 14-Apr & 1 & 0 & 0 \\
\hline 23 & 15-Apr & 3 & 0 & 0 \\
\hline 24 & 16-Apr & 15 & 1 & 0 \\
\hline 25 & 17-Apr & 17 & 0 & 0 \\
\hline 26 & 18-Apr & 30 & 0 & 0 \\
\hline 27 & 19-Apr & 5 & 0 & 1 \\
\hline 28 & 20-Apr & 0 & 0 & 0 \\
\hline 29 & 21-Apr & 0 & 0 & 0 \\
\hline 30 & 22-Apr & 0 & 0 & 0 \\
\hline 31 & 23-Apr & 4 & 0 & 0 \\
\hline 32 & 24-Apr & 13 & 0 & 0 \\
\hline 33 & 25-Apr & 13 & 0 & 0 \\
\hline 34 & 26-Apr & 10 & 13 & 0 \\
\hline 35 & 27-Apr & 1 & 0 & 0 \\
\hline
\end{tabular}


Analisis Penyebaran Virus...Jupiter... Vol 2 No 1...Juli 2020...12-23

Widya Rahmadani, Sagita Charolina Sihombing

\begin{tabular}{|c|c|c|c|c|}
\hline 36 & 28-Apr & 13 & 4 & 0 \\
\hline 37 & 29-Apr & 1 & 0 & 0 \\
\hline 38 & 30-Apr & 6 & 1 & 0 \\
\hline 39 & 1-May & 6 & 6 & 0 \\
\hline 40 & 2-May & 0 & 0 & 0 \\
\hline 41 & 3-May & 29 & 7 & 1 \\
\hline 42 & 4-May & 0 & 7 & 1 \\
\hline 43 & 5-May & 14 & 4 & 0 \\
\hline 44 & 6-May & 11 & 0 & 0 \\
\hline 45 & 7-May & 17 & 0 & 1 \\
\hline 46 & 8-May & 0 & 2 & 0 \\
\hline 47 & 9-May & 51 & 0 & 0 \\
\hline 48 & 10-May & 0 & 6 & 3 \\
\hline 49 & 11-May & 0 & 9 & 0 \\
\hline 50 & 12-May & 1 & 0 & 0 \\
\hline 51 & 13-May & 43 & 9 & 0 \\
\hline 52 & 14-May & 119 & 0 & 0 \\
\hline 53 & 15-May & 17 & 0 & 0 \\
\hline 54 & 16-May & 0 & 0 & 2 \\
\hline 55 & 17-May & 63 & 0 & 0 \\
\hline 56 & 18-May & 16 & 0 & 2 \\
\hline 57 & 19-May & 60 & 4 & 5 \\
\hline 58 & 20-May & 49 & 0 & 1 \\
\hline 59 & 21-May & 28 & 1 & 2 \\
\hline 60 & 22-May & 19 & 17 & 1 \\
\hline 61 & 23-May & 32 & 5 & 1 \\
\hline 62 & 24-May & 11 & 2 & 2 \\
\hline 63 & 25-May & 76 & 10 & 0 \\
\hline 64 & 26-May & 56 & 2 & 0 \\
\hline 65 & 27-May & 47 & 0 & 0 \\
\hline 66 & 28-May & 26 & 9 & 0 \\
\hline 67 & 29-May & 12 & 14 & 2 \\
\hline 68 & 30-May & 10 & 32 & 4 \\
\hline 69 & 31-May & 19 & 34 & 3 \\
\hline
\end{tabular}

Untuk melihat lebih jelas pasien meninggal dunia, dapat dilihat perkembangan dari masing-masing kasus pada gambar 2 di bawah ini: yaitu pasien positif, pasien sembuh dan 
Analisis Penyebaran Virus...Jupiter... Vol 2 No 1...Juli 2020...12-23

Widya Rahmadani, Sagita Charolina Sihombing

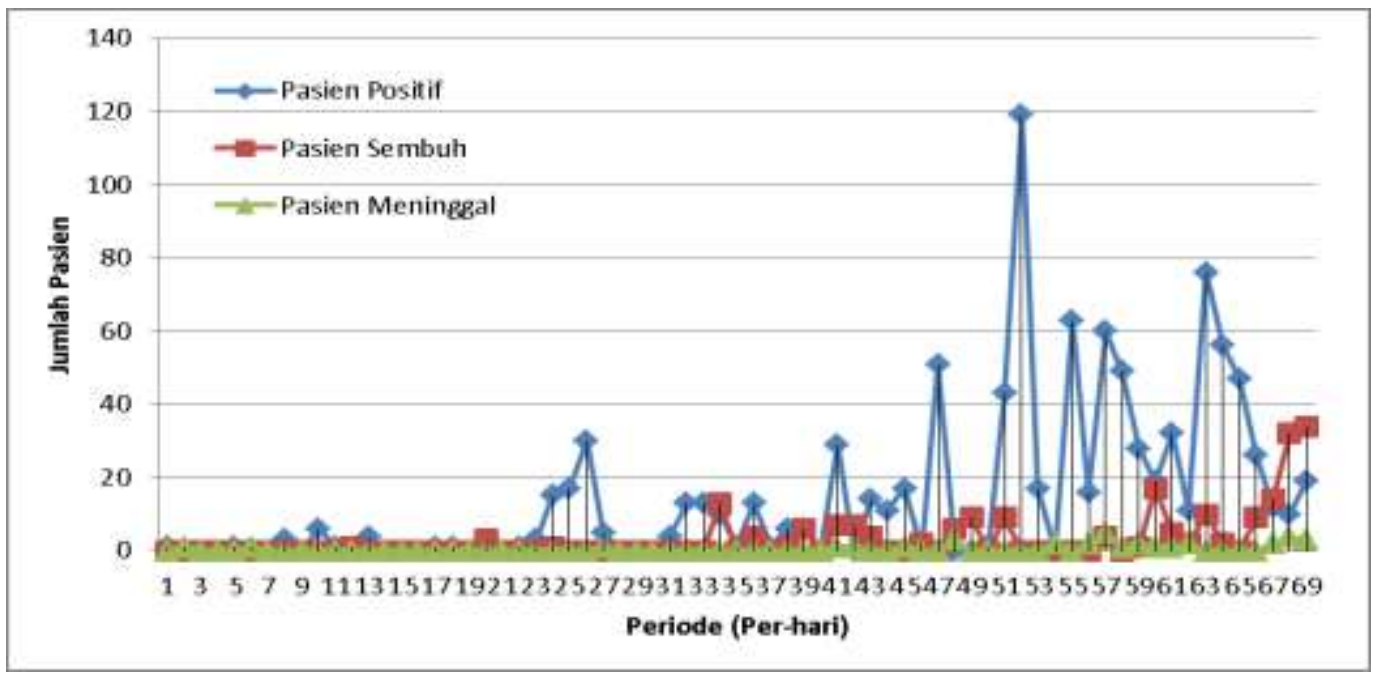

Gambar 2. Grafik Data Pasien Covid-19 di Provinsi Sumatera Selatan per-hari mulai dari 24 Maret 2020 sampai 31 Mei 2020

\section{Tahapan Penelitian}

Tahapan yang dilakukan untuk memprediksi perkembangan dari penularan, kesembuhan maupun kematian dengan data virus corona melalui metode interpolasi lagrange adalah sebagai berikut:

a. Identifikasi Masalah

Pada tahapan ini penulis mengumpulkan referensi terkait data virus corona, dan referensi pendukung lainnya, serta referensi tentang interpolasi Lagrange.

b. Pengambilan dan Validasi Data

Pada tahapan ini penulis mengambil data virus corona pada awal terdeteksinya kasus pertama di Sumatera Selatan yaitu pada tanggal 24 Maret 2020 sampai 31 Mei 2020 yang ditulis dengan hari ke-1 sampai ke-69 untuk melakukan simulasi dan akan diakumulasikan perbulannya.

c. Perancangan, Implementasi dan Prediksi

Pada tahapan ini penulis merancang data virus corona menggunakan Microsoft excel dan mengimplementasikannya

menggunakan MATLAB untuk mencari perkembangan dari penularan virus corona pada bulan ke 6, 7, dan 8 yaitu Juni, Juli dan Agustus dimana data awal yang digunakan sebanyak 3 titik yaitu bulan Maret, April dan Mei.

d. Analisa dan Pembahasan Pada tahap ini penulis melakukan analisa data dari hasil simulasi yang dilakukan menggunakan metode interpolasi Lagrange dan membahas hasil simulasi tersebut. Sehingga dari data virus corona yang telah didapat dilakukan forecasting dan simulasi dengan metode interpolasi Lagrange untuk memprediksi perkembangan virus corona untuk bulan-bulan berikutnya.

\section{HASIL DAN PEMBAHASAN}

a. Hasil Simulasi Pasien Positif Covid19

Dari data kasus positif corona mulai tanggal 24 Maret 2020 sampai 31 Mei 2020 dimana dikelompokkan perbulannya, dapat diprediksi perkembangan kasus virus corona pada bulan Juni, Juli dan Agustus pada gambar grafik 3 berikut : 


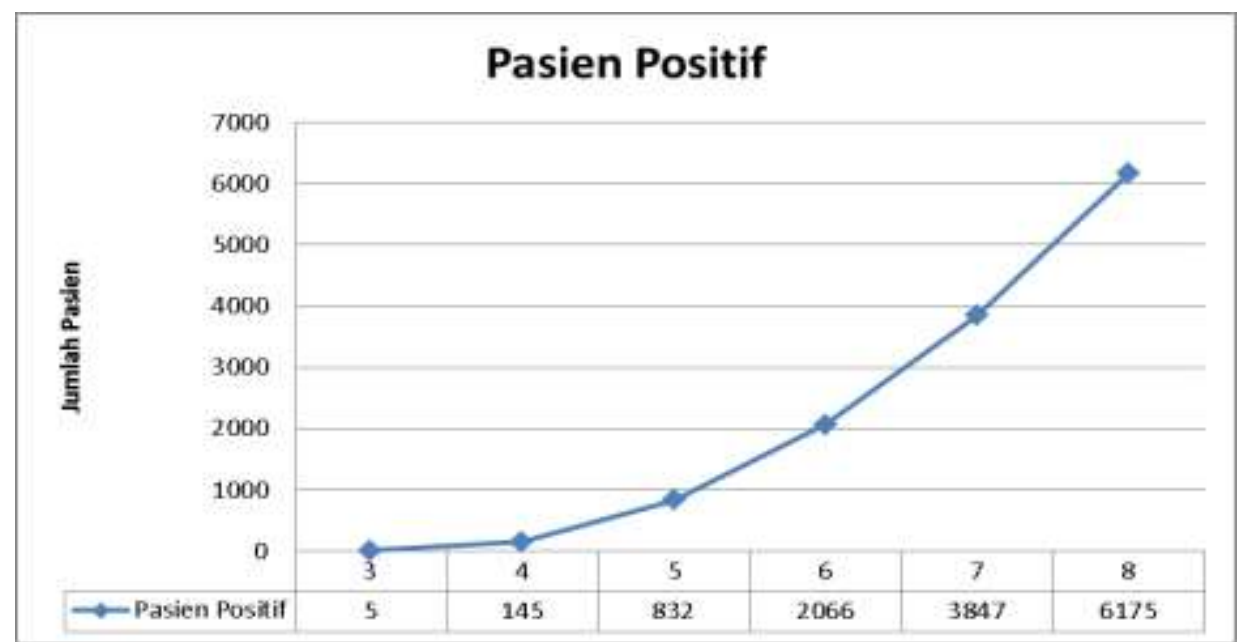

Gambar 3. Prediksi Pasien Positif Covid-19 bulan Juni, Juli dan Agustus

Berdasarkan prediksi perhitungan gambar 3 diatas yang menunjukkan hasil forecast dari data pasien yang terkonfirmasi positif Covid-19 sejak awal masuknya di Sumatera Selatan yaitu pada akhir bulan Maret sampai bulan Mei, untuk memprediksi perkembangan kasus pada bulan Juni, Juli dan Agustus 2020, terlihat pada grafik mengalami peningkatan kasus pasien positif Covid19. Dari hasil simulasi dapat diprediksikan akan terjadi peningkatan kasus positif di bulan Juni sebanyak 2.066 kasus, bulan Juli sebanyak 3.847 kasus dan bulan Agustus sebanyak 6.175 kasus.

Tabel 2. Hasil Simulasi Forecast Pasien Positif Menggunakan Interpolasi Lagrange

\begin{tabular}{ccc}
\hline Bulan ke- & Nama Bulan & Pasien Positif \\
\hline 3 & Maret & 5 \\
4 & April & 145 \\
5 & Mei & 832 \\
6 & Juni & 2066 \\
7 & Juli & 3847 \\
8 & Agustus & 6175 \\
\hline
\end{tabular}

Dari hasil pada tabel 2 dan gambar 3 diatas diperoleh persamaan interpolasi polynomial Lagrangenya (model matematika) dari hasil simulasi MATLAB, adalah sebagai berikut:

$$
\begin{aligned}
P(x) & =\frac{\left(x-x_{1}\right)\left(x-x_{2}\right)}{\left(x_{0}-x_{1}\right)\left(x_{0}-x_{2}\right)} \cdot y_{0}+\frac{\left(x-x_{0}\right)\left(x-x_{2}\right)}{\left(x_{1}-x_{0}\right)\left(x_{1}-x_{2}\right)} \cdot y_{1}+\frac{\left(x-x_{0}\right)\left(x-x_{1}\right)}{\left(x_{2}-x_{0}\right)\left(x_{2}-x_{1}\right)} \cdot y_{2} \\
& =\frac{(x-4)(x-5)}{(3-4)(3-5)} \cdot 5+\frac{(x-3)(x-5)}{(4-3)(4-5)} \cdot 145+\frac{(x-3)(x-4)}{(5-3)(5-4)} \cdot 832 \\
& =\frac{(x-4)(x-5)}{2} \cdot 5+\frac{(x-3)(x-5)}{-1} \cdot 145+\frac{(x-3)(x-4)}{2} \cdot 832
\end{aligned}
$$

Berdasarkan hasil prediksi di peningkatan cukup tinggi pada kasus bulan Juni, Juli dan Agustus 2020, terjadi positif Covid-19 di Sumatera Selatan. 


\section{Analisis Penyebaran Virus...Jupiter... Vol 2 No 1...Juli 2020...12-23 \\ Widya Rahmadani, Sagita Charolina Sihombing}

Dengan meningkatnya kasus positif dalam waktu tiga bulan kedepan, dibutuhkan antisipasi yang lebih ketat dalam pencegahan penularan virus corona seperti halnya dengan memperketat aturan PSBB, menutup sementara fasilitas-fasilitas umum yang dapat mengumpulkan orang banyak, menghentikan sementara laju moda transportasi keluar daerah baik darat maupun laut dan mengedukasi masyarakat secara keseluruhan tentang pentingnya menjaga kesehatan dan social distancing.

\section{b. Hasil Simulasi Pasien Sembuh}

\section{Covid-19}

Dari data kasus pasien sembuh yang terkonfirmasi mulai tanggal 4 April 2020 sampai 31 Mei 2020 dimana dikelompokkan perbulannya, dapat diprediksi perkembangan kasus pasien yang sembuh dari Covid-19 pada bulan Juni, Juli dan Agustus pada gambar grafik 4 berikut :

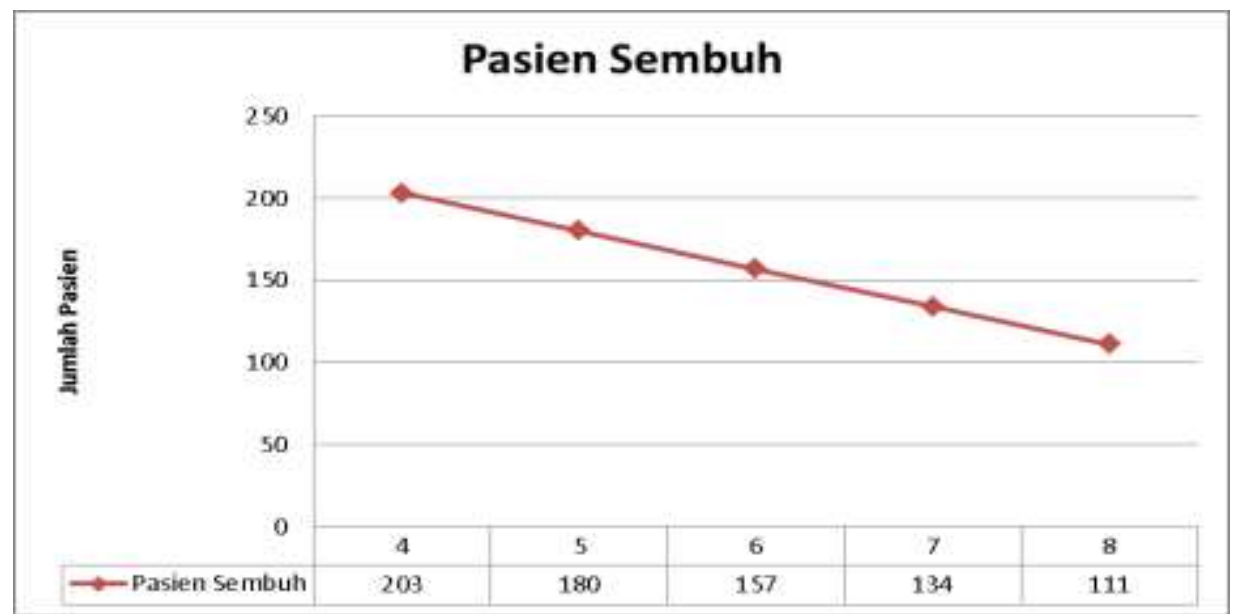

Gambar 4. Prediksi Pasien Sembuh Covid-19 bulan Juni, Juli dan Agustus

Berdasarkan prediksi perhitungan gambar 4 diatas yang menunjukkan hasil forecast dari data pasien yang terkonfirmasi sembuh dari Covid-19 pada bulan April sampai Mei, untuk memprediksi perkembangan kasus pada bulan Juni, Juli dan Agustus 2020, terlihat pada grafik mengalami penurunan kasus pasien yagn sembuh dari Covid-19. Dari hasil simulasi dapat diprediksikan akan terjadi penurunan kasus pasien yang sembuh di bulan Juni sebanyak 157 kasus, bulan Juli sebanyak 134 kasus dan bulan Agustus sebanyak 111 kasus.

Tabel 3. Hasil Simulasi Forecast Pasien Sembuh Menggunakan Interpolasi Lagrange

\begin{tabular}{ccc}
\hline Bulan ke- & Nama Bulan & Pasien Sembuh \\
\hline 3 & Maret & 0 \\
4 & April & 203 \\
5 & Mei & 180 \\
6 & Juni & 157 \\
7 & Juli & 134 \\
8 & Agustus & 111 \\
\hline
\end{tabular}




\section{Analisis Penyebaran Virus...Jupiter... Vol 2 No 1...Juli 2020...12-23}

Widya Rahmadani, Sagita Charolina Sihombing

Dari hasil pada tabel 3 dan gambar 4 diatas diperoleh persamaan interpolasi polynomial Lagrangenya (model matematika) dari hasil simulasi MATLAB, adalah sebagai berikut :

$$
\begin{aligned}
P(x) & =\frac{\left(x-x_{1}\right)}{\left(x_{0}-x_{1}\right)} \cdot y_{0}+\frac{\left(x-x_{0}\right)}{\left(x_{1}-x_{0}\right)} \cdot y_{1} \\
& =\frac{(x-5)}{(4-5)} \cdot 203+\frac{(x-4)}{(5-4)} \cdot 180 \\
& =\frac{(x-5)}{-1} \cdot 203+\frac{(x-4)}{1} \cdot 180
\end{aligned}
$$

Berdasarkan hasil prediksi bulan Juni, Juli dan Agustus 2020 untuk kasus pasien sembuh dari Covid-19 terjadi penurunan pasien dalam tiga bulan kedepan. Hal ini kemungkinan bisa terjadi disebabkan faktor meningkatnya kasus positif tiap bulannya, di dukung dengan kurangnya fasilitas dan alat-alat kesehatan yang dimiliki. Sehingga meningginya kasus positif khususnya yang membutuhkan pelayanan khusus, dan kapasitas Rumah Sakit yang overload, bisa menjadi pemicu menurunnya pasien yang sembuh.

c. Hasil Simulasi Pasien Meninggal Dunia Covid-19

Dari data kasus pasien meninggal akibat virus corona mulai tanggal 24 Maret 2020 sampai 31 Mei 2020 dimana dikelompokkan perbulannya, dapat diprediksi perkembangan kasus pasien meninggal pada bulan Juni, Juli dan Agustus pada gambar grafik 5 berikut :

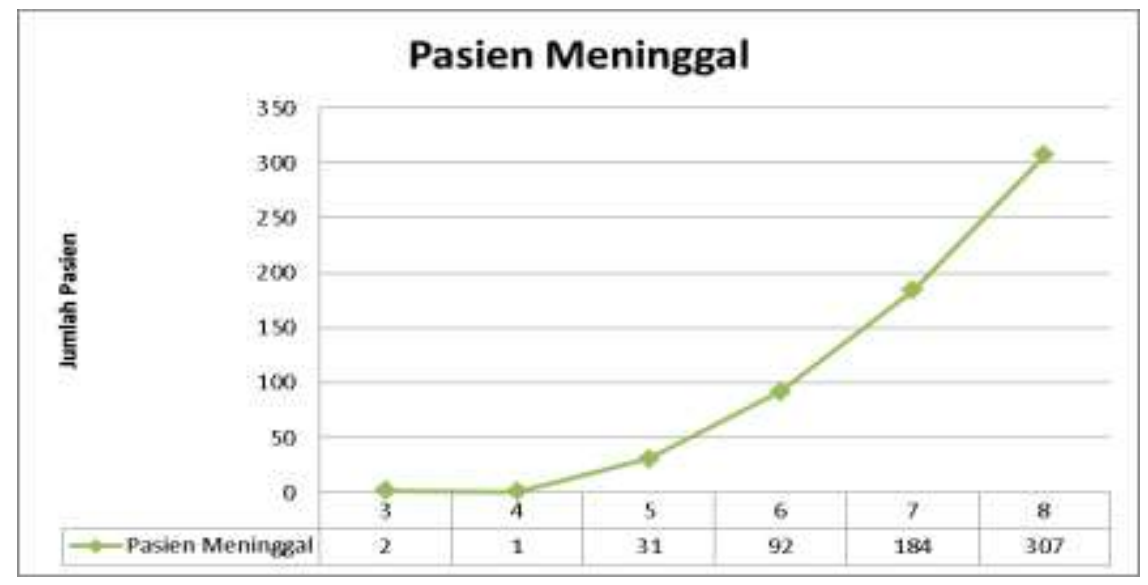

Gambar 5. Prediksi Pasien Meninggal akibat Covid-19 bulan Juni, Juli dan Agustus

Berdasarkan prediksi perhitungan gambar 5 diatas yang menunjukkan hasil forecast dari data pasien yang meninggal akibat Covid-19, terhitung pada akhir bulan Maret sampai bulan Mei, untuk memprediksi perkembangan kasus pada bulan Juni, Juli dan Agustus 2020, terlihat pada grafik mengalami peningkatan kasus pasien meninggal akibat Covid-19. Dari hasil simulasi dapat diprediksikan akan terjadi peningkatan kasus pasien meninggal di bulan Juni sebanyak 92 kasus, bulan Juli sebanyak 184 kasus dan bulan Agustus sebanyak 307 kasus.

Tabel 4. Hasil Simulasi Forecast Pasien Meninggal Menggunakan Interpolasi Lagrange

\begin{tabular}{ccc}
\hline Bulan ke- & Nama Bulan & Pasien Meninggal \\
\hline 3 & Maret & 2 \\
4 & April & 1 \\
5 & Mei & 31
\end{tabular}




\begin{tabular}{lcc}
6 & Juni & 92 \\
7 & Juli & 184 \\
8 & Agustus & 307 \\
\hline
\end{tabular}

Dari hasil pada tabel 4 dan gambar 5 diatas diperoleh persamaan interpolasi polynomial Lagrangenya

$$
\begin{aligned}
P(x) & =\frac{\left(x-x_{1}\right)\left(x-x_{2}\right)}{\left(x_{0}-x_{1}\right)\left(x_{0}-x_{2}\right)} \cdot y_{0}+\frac{\left(x-x_{0}\right)\left(x-x_{2}\right)}{\left(x_{1}-x_{0}\right)\left(x_{1}-x_{2}\right)} \cdot y_{1}+\frac{\left(x-x_{0}\right)\left(x-x_{1}\right)}{\left(x_{2}-x_{0}\right)\left(x_{2}-x_{1}\right)} \cdot y_{2} \\
& =\frac{(x-4)(x-5)}{(3-4)(3-5)} \cdot 2+\frac{(x-3)(x-5)}{(4-3)(4-5)} \cdot 1+\frac{(x-3)(x-4)}{(5-3)(5-4)} \cdot 31 \\
& =\frac{(x-4)(x-5)}{2} \cdot 2+\frac{(x-3)(x-5)}{-1} \cdot 1+\frac{(x-3)(x-4)}{2} \cdot 31
\end{aligned}
$$

(model matematika) dari hasil simulasi MATLAB, adalah sebagai berikut :
Berdasarkan hasil prediksi di bulan Juni, Juli dan Agustus untuk kasus pasien meninggal akibat virus corona mengalami peningkatan yang cukup

\section{KESIMPULAN}

Kesimpulan berdasarkan hasil penelitian menunjukkan bahwa perkembangan penularan virus corona di Provinsi Sumatera Selatan terus mengalami peningkatan dari jumlah kasus yang ada, terlihat dari data pasien positif Covid-19 yang pada awalnya hanya berjumlah 1 orang menjadi 832 kasus pada tanggal 31 Mei 2020, sehingga dari data kasus yang telah disimulasikan dapat diprediksi bahwa untuk tiga bulan kedepan yaitu Juni, Juli dan Agustus 2020 akan mengalami peningkatan jumlah kasus positif Covid19 mencapai 6.175 kasus di bulan Agustus, sedangkan jumlah kasus pasien sembuh mengalami penurunan yaitu mencapai 111 kasus di bulan Agustus, serta jumlah kasus pasien meninggal akan mengalami peningkatan mencapai 307 kasus di bulan Agustus 2020. Menurunnya kasus pasien sembuh dari Covid-19, kemungkinan bisa disebabkan oleh tingginya tingkat kasus positif Covid-19 dan minimnya fasilitas dan ketersediaan alat-alat kesehatan yang diperlukan, sehingga diprediksi dapat tinggi. Hal ini kemungkinan bisa terjadi karena minimnya fasilitas kesehatan dan dampak dari meningkatnya kasus positif Covid-19 di provinsi Sumatera Selatan.

mengakibatkan penambahan kasus kematian pasien akibat Covid-19 dalam waktu tiga bulan kedepan.

Dari hasil penelitian dan hasil prediksi yang telah dilakukan, diperoleh bahwa penerapan metode interpolasi Lagrange dapat digunakan untuk meramalkan data kasus virus corona baik untuk kasus pasien positif, pasien sembuh maupun pasien meninggal dari awal masuknya kasus pertama di Provinsi Sumatera Selatan yaitu bulan Maret sampai Mei 2020. Dari data real tersebut dapat diketahui peramalan data pada bulan-bulan berikutnya dan ternyata hasil prediksi perkembangan virus corona di bulan Juni, Juli dan Agustus mengalami peningkatan untuk kasus pasien positif dan pasien meninggal, serta penurunan untuk kasus pasien sembuh dari Covid-19 yang cukup signifikan. Sehingga hasil prediksi ini diharapkan dapat dijadikan pertimbangan bagi pemerintah daerah untuk lebih serius dalam menangani dan menghentikan laju perkembangan penularan virus corona di Provinsi Sumatera Selatan, agar tidak terjadi peningkatan kasus positif dan pasien meninggal akibat Covid-19. 


\section{DAFTAR PUSTAKA}

Dinkes Sumatera Selatan. (2020). Update Situasi Covid-19 Sumsel, 9 Juni 2020.

http://dinkes.sumselprov.go.id/20 20/06/update-situasi-covid-19sumsel-9-juni-2020/

Korsman, S.N.J., van Zyl, G.U., Nutt, L., Andersson, M.I, Presier, W. (2012). Viroloy. Chins: Churchill Livingston Elsevier.

Krisnawati. (2007). Implementasi Interpolasi Lagrange Untuk Prediksi Nilai Data Berpasangan Dengan Menggunakan Matlab. Seminar Nasional Teknologi 2007 (SNT 2007) (pp. 1-7). Yogyakarta: STMIK AMIKOM Yogyakarta.

Perhimpunan Dokter Paru Indonesia. (2020). Panduan Praktik Klinis: Pneumonia 2019-nCoV. PDPI: Jakarta.

Sucipto, Lalu, dan Syaharuddin. (2018). Konstruksi Forecasting System Multi-Model Untuk Pemodelan Matematika Pada Peramalan Indeks Pembangunan Manusia
Provinsi Nusa Tenggara Barat. Register: Jurnal Ilmiah Teknologi Sistem Informasi 4(2): 114.

Telaumbanua, Dalinama. (2020). Urgensi

Pembentukan Aturan Terkait

Pencegahan Covid-19 di

Indonesia. QALAMUNA: Jurnal

Pendidikan, Sosial dan Agama 12(01): 59-70.

Yuliana. (2020). Corona Virus Diseases (Covid-19); Sebuah Tinjauan Literatur. Wellness And Healthy Magazine : Lampung.

Yulianto, Tony., Nur I U, dan Rica Amalia. (2016). Peramalan HIV Menggunakan Interpolasi Lagrange. Zeta - Math Journal 2(1).

Yunus, Nur Rohim, dan Annissa Rezki. (2020). Kebijakan Pemberlakuan Lock Down Sebagai Antisipasi Penyebaran Corona Virus Covid19. SALAM: Jurnal Sosial dan Budaya Sya-I 7(3).

Wang, Z., Qiang, W., Ke, H. (2020). A Handbook of 2019-nCoV Pneumonia Control and Prevention. Hubei Science and Technologi Press: China. 